\begin{tabular}{lccr} 
A R C H I V E & O F & M E C H A N I C A L & E N G I N E E R I N G \\
\hline VOL. LXII & 2015 & Number 1
\end{tabular}

10.1515/meceng-2015-0004

Key words: capstan speed, experiment, tuner roll machine, wire drawing

\title{
EXPERIMENTAL MEASUREMENTS OF SYSTEM DYNAMICS BETWEEN TWO STAGES OF WIRE DRAWING MACHINE
}

\begin{abstract}
In multi-stage wire drawing machines productivity growth can be achieved at higher drawing speeds by preventing wire breakage during the process. One disadvantage of high-speed wire drawing is the requirement imposed by machine dynamics in terms of its stability and reliability during operation. Tensile forces in the wire must maintained by fast synchronization of all capstans speed. In this process, the displacement sensors play the main role in providing the control system with feedback information about the wire condition. In this study, the influences between the sensors and actuator driven capstans have been studied, and tuner roll concept of a wire drawing machine was experimentally investigated. To this aim, measurements were carried out on two drawing stages at different drawing speeds and obtained results were presented. These results clearly show the fast changes of the capstans speed and the angular displacements of the rollers that tighten the wire, which only confirms the high dynamics of the wire drawing machine.
\end{abstract}

\section{Introduction}

Wire drawing is the most common manufacturing method used to reduce the diameter of wires by pulling the wire through a die [1-2]. The products obtained by drawing process receive the desired physical and mechanical properties (elasticity, plasticity) with exactly defined geometric features. In comparison to rolling and extrusion, drawing offers much better dimensional control, continuous processing, lower capital equipment cost and extension to small cross sections [3].

In the wire drawing process, a number of factors need to be controlled in order to obtain the necessary dimensions for the wire. High-speed wire draw-

* St. Cyril and Methodius University, Faculty of Mechanical Engineering, Skopje, R. Macedonia; E-mail: goce.tasevski@mf.edu.mk, kocho.angjushev@mf.edu.mk, zlatko.petreski@mf.edu.mk,siskovskidental@yahoo.com 
ing has become very common recently, because of an increase in customer demand and an increase in industrial rates of production [4].

Lee et al. [5], clarify that maximum productivity of a wire drawing process means that the drawing speed has to be increased as fast as possible without wire-breaks or deterioration of the qualities of the final drawn wire. Namely, in a multi-stage drawing process, by using a series of dies, the wire diameter is continuously reduced during several stages until it reaches the final diameter. Significant downtime in the operation of the machine could occur if wire breaks happen during the wire drawing process. This will cause the process to stop and time for preparation of the wire will be required. As a reflection of that condition, significant decrease in the productivity will appear. However, one drawback to higher drawing speed is the necessity for stable and reliable drawing machine dynamics [3].

In multi-stage drawing, wire gets longer at each stage after reduction. Therefore, in order to maintain equal volumetric rate of metal flow at all dies, each capstan must turn faster than the one before [6], where angular velocity of each capstan must be equal to the exiting wire speed from the dies. In cases where this requirement cannot be achieved, drawing force which is created by actuator driven capstans will pull the wire harder than usual, so the wire will break due to unequal wire tension between dies. Theoretically, wire velocity at any stage can be calculated if the input wire speed in the drawing die and the rate of reduction are known.

Because of being exposed to high pressures and temperatures, drawing dies are subjected to wear. As a consequence, wire diameter increases, and due to the fact that constant mass flow must be maintained, wire speed will decreases as the dies increase in size [7]. Moreover, as the wire diameter increases, capstan speed becomes faster than the wire speed, so the wire can break due to the high tensile stress.

In practice, this can be overcome with several methods. The simplest and the oldest among them, as noted in [6], is applied when the wire is allowed to slip slightly as it goes around each capstan. However, from a practical standpoint, this method is used less frequently, as it may cause damage to the surface of the wire. Another method, different from the previous one, which allows drawing the wire at very high speeds, involves both variable speed drives on each capstan and tension sensing device (dancer arm) to control the speed. Many different solutions of a dancer arm wire drawing machines are given in [8].

Nowadays, tuner toll wire drawing machines are one of the most widely used designs which are basically a kind of improved dancer arm concept. Here, the process goes faster as the wire takes almost straight line path, unlike the dancer arm design where the wire is bending through supplemental 
pulleys. A moveable roller is installed between two consecutive capstans, pressed against the wire, in order to give the control system information about the condition of the wire between the two stages, whether the wire is stressed or has a loose loop [9]. Namely, the roller has an important role as a displacement sensor whose signals are converted to electrical signals to PLC controller, in order to achieve tension stability [10]. On the other hand, based on the system continuity, every roller movement affects the actuators speeds that drive the capstans (see Fig. 1).

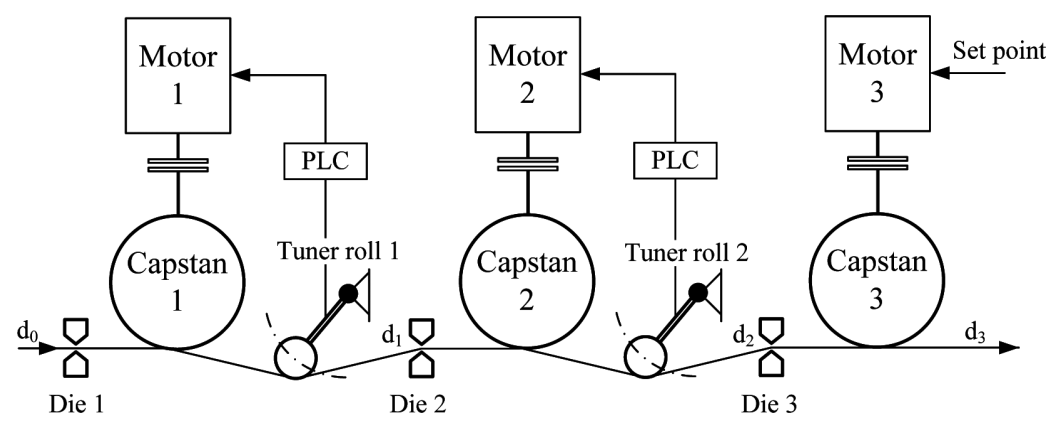

Fig. 1. Tuner roll principle of a wire drawing machine

In the cases when the disturbance in the system occurs, fast synchronization of all the actuators speed must be accomplished to retain the wire tension within the permissible limits. Fulfilling this requirement may contribute to avoiding wire-breaks during the process. Thus, wire drawing machine can continue its uninterrupted work. Control system parameters should be properly set up to be able to follow the fast system dynamics, which can best be seen if we monitor the relationship between the movements of the rollers and the speed of the capstans driven by electric motors. The rollers provide feedback signals in the control loop of the system which are very important for synchronization of all actuators speeds.

This paper shows the influence between two consecutive drawing stages where the experimental examination is carried out on two rollers and two capstans. Performance measurements may contribute to acquiring the knowledge on control system response regarding the maintenance of stable condition of the process.

The remaining parts of this paper are structured as follows: section 2 describes the experimental procedure in detail, while results obtained from the measurements are presented in section 3 , and subsequent conclusions are presented in section 4 . 


\section{Experimental procedure}

The research was conducted on a wire drawing machine of type LZ13/560 which consists of 13 drawing stages with $560 \mathrm{~mm}$ capstan diameters. First drawing stage had a $37 \mathrm{~kW}$ AC induction motor, unlike other drawing stages, each of whom was driven by a $30 \mathrm{~kW}$ AC induction squirrel-cage motors. The wire which was drawn in the process was SAE1045 type with input diameter of $5.5 \mathrm{~mm}$. During the experiment, 11 out of 13 drawing stages from the wire drawing machine were used, where the reduction ratio between 10th and 11th stage was $21.4 \%$ and between 9th and 10th stage was $24.6 \%$.

Hence, the experiment was set to last three stages of the machine, whereby the last drawing stage were running at constant speed, enabled through an external touch panel. Two optical sensors, produced by Bruel \& Kjaer and from SKF, were used to measure the angular speed of the two capstans by triggering off of reflective tape placed on the capstans surface, as shown in Fig. 2. The data obtained from these sensors were processed in LabView environment. To transfer the measured data, NI 9423 8-channel high-speed digital input module was used.

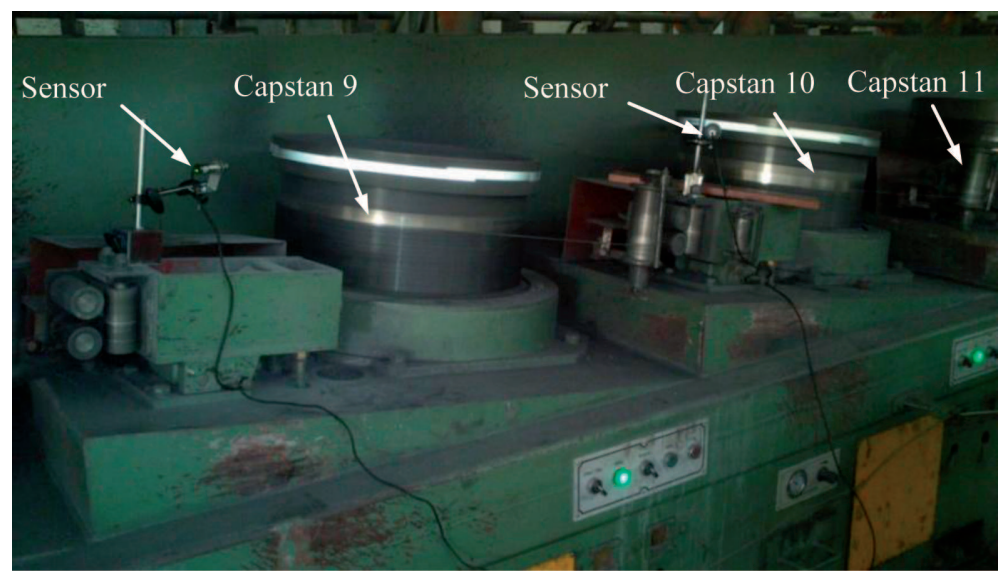

Fig. 2. Sensors positions for measuring the capstans speed

Angular position of the tuner roll was determined by an inductive sensor shown in Fig. 3. This inductive sensor measured the distance from the cam mechanism, giving as output electric signal in the range of 4 to $20 \mathrm{~mA}$. Electric current signals that indicate the movements of both tuner rolls were not dependent on each other (galvanically separated).

Since the measurement of the rollers positions should be done during working conditions of the machine, and should not to disturb its continued 
operation, $22 \Omega$ resistors were added in a serial link to electric current signals. The value of the resistors was carefully chosen in order not to affect the proper functioning of the machine.

Using Ohm's Law, one can measure voltage drop in the resistors and hence tuner rolls positions can be determined. The voltage drop was measured with NI 9207 which represented 16-Channel, $\pm 20 \mathrm{~mA} / \pm 10 \mathrm{~V}, 24$-Bit analog input module.

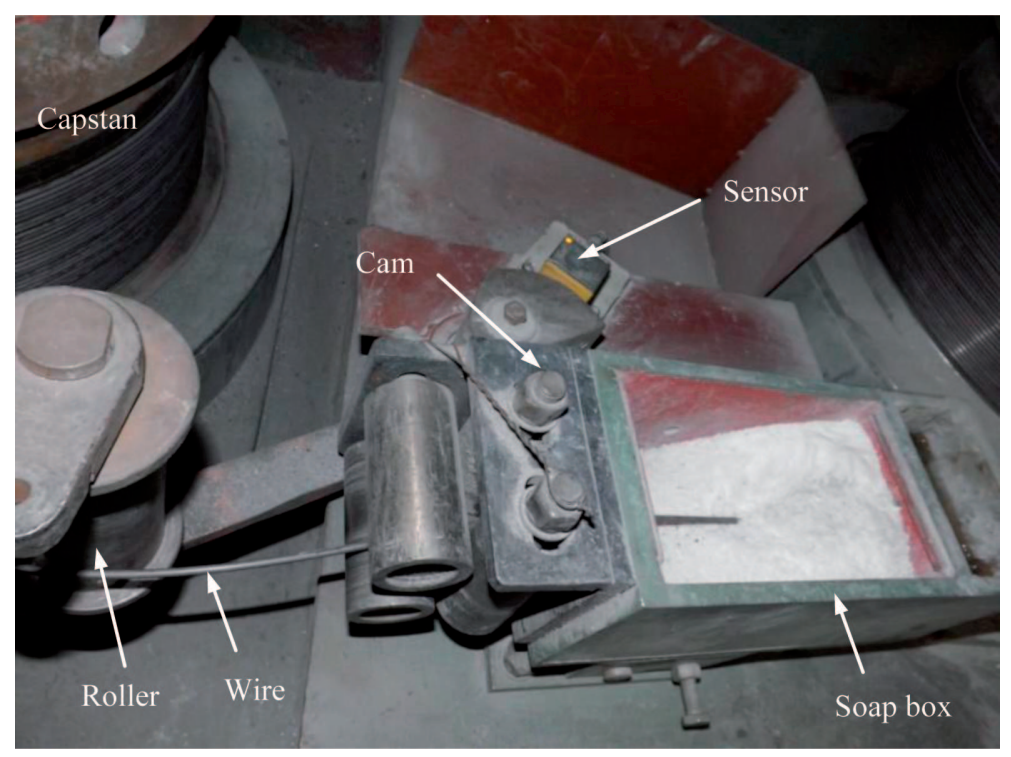

Fig. 3. Location of the inductive sensor that measures the position of the roller

Two optical sensors from Bruel \& Kjaer and from SKF that we applied gave output signals from a $5 \mathrm{~V}$ and $7.2 \mathrm{~V}$. To adjust the output signals from these sensors to the input signals of the NI 9423 and NI 9207 modules, a two channel electric module (Fig. 4) was designed.

This module solved the problems of stable voltage supply to the optical sensors and signals conditioning. The Schmitt trigger integrated circuit was additionally placed in the module to remove the electric noise that may appear in digital signals from the optical sensors. The signals representing the tuner rolls positions were connected to the NI 9207 module. On the other hand, capstans speed signals measured by the optical triggers were linked to the input ports of the electric module. After the conversion of these signals, the output ports of the electric module were directly connected with NI 9423 module. These two modules were mounted in NI cDAQ-9174, a 4 slot chassis, which communicated with a PC via USB connections. 


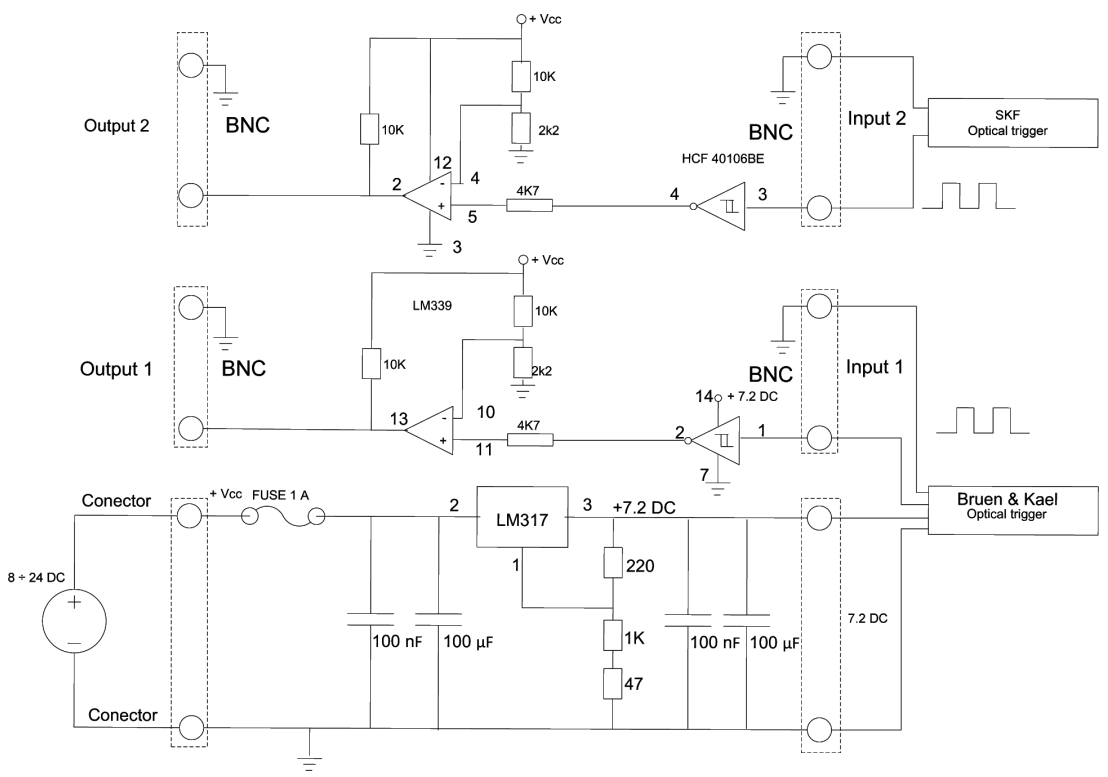

Fig. 4. Electric scheme of the module

\section{Experimental results}

The experiment was carried out in such a way that constant drawing speed of the wire was set through the outer touch panel. This procedure was repeated four times with drawing speeds of 3,5,7 and $9 \mathrm{~m} / \mathrm{s}$. Wire drawing machine dynamics was tested during the start-up conditions, steady state operation and slowing down process. Fig. 5 to Fig. 8 represent the capstans speed.

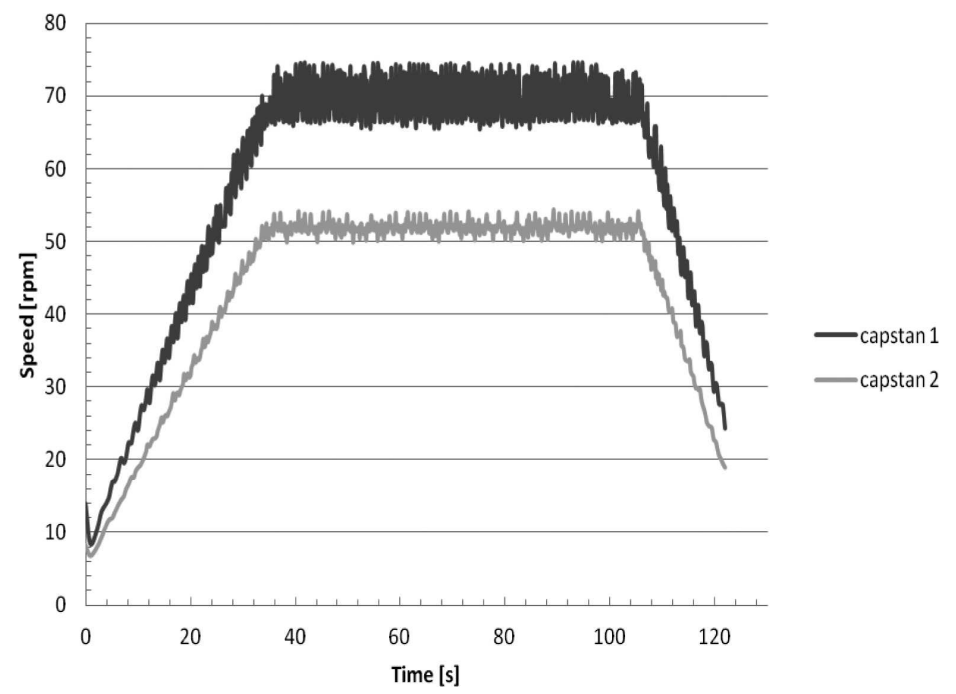

Fig. 5. Capstans speed measured at $3 \mathrm{~m} / \mathrm{s}$ drawing speed 


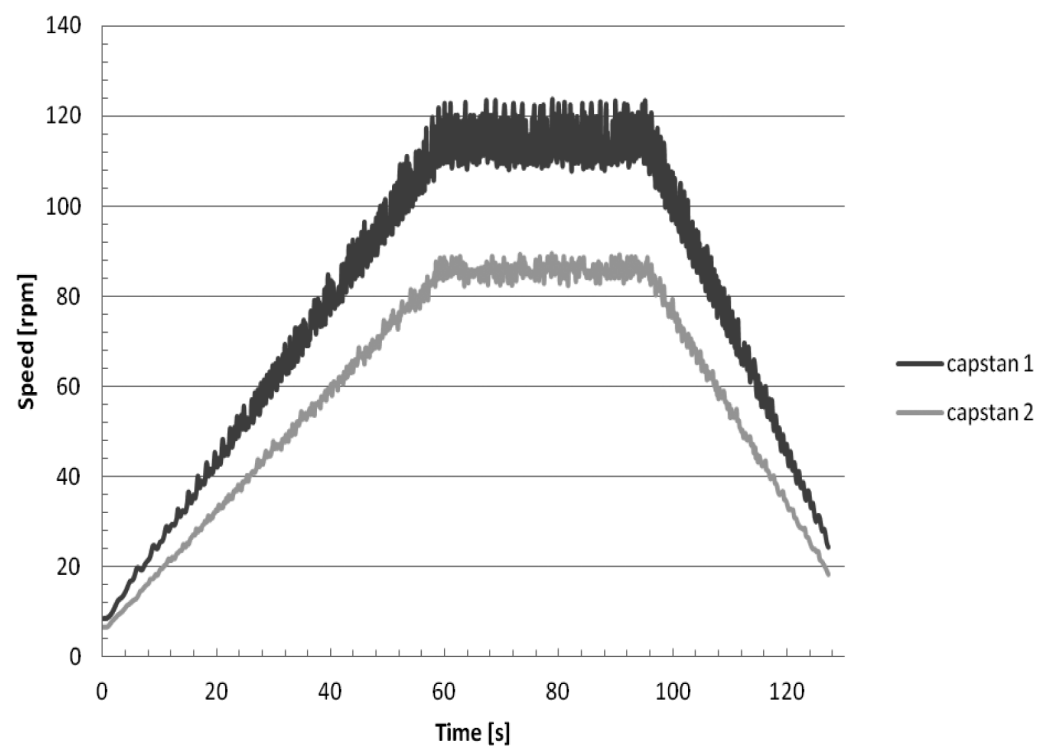

Fig. 6. Capstans speed measured at $5 \mathrm{~m} / \mathrm{s}$ drawing speed

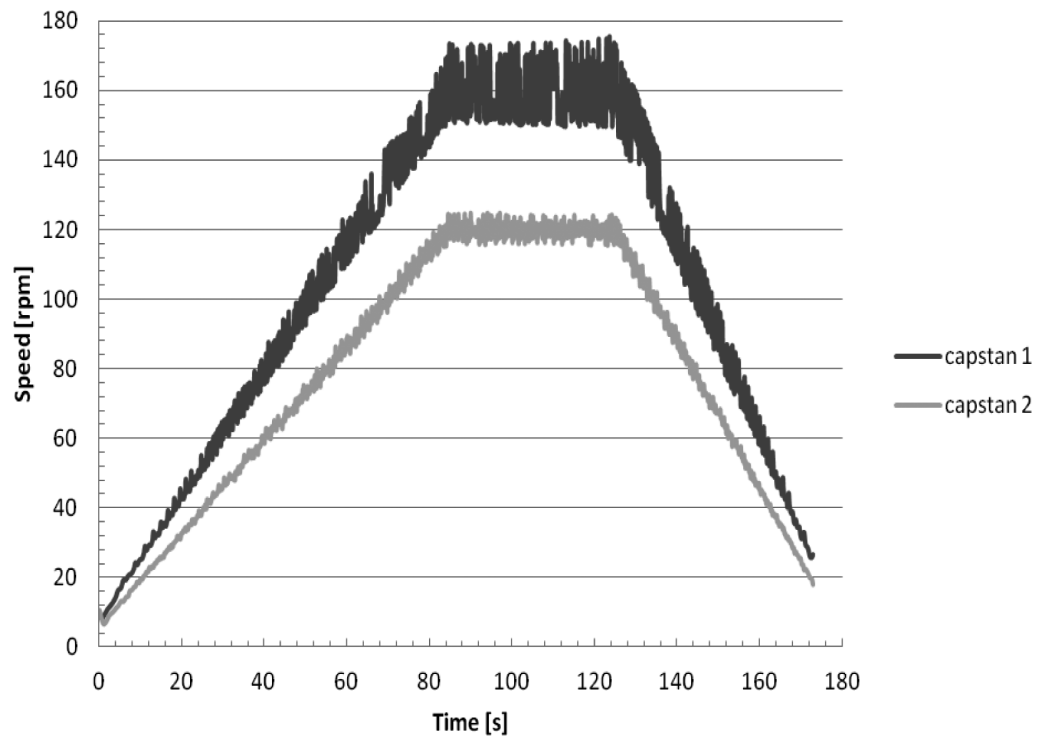

Fig. 7. Capstans speed measured at $7 \mathrm{~m} / \mathrm{s}$ drawing speed

Angular displacements of the tuner rolls placed between these capstans were measured in the same range of drawing speeds during the same working conditions of the machine. The results are given below in Figs. 9 to 12. 


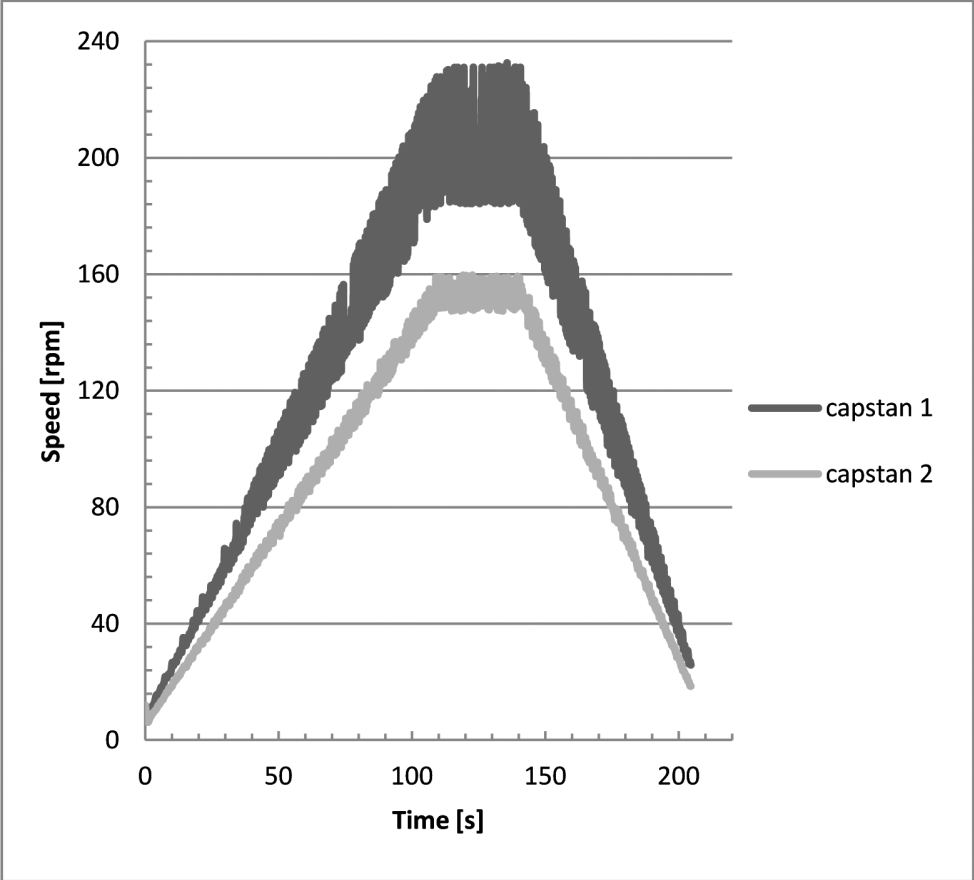

Fig. 8. Capstans speed measured at $9 \mathrm{~m} / \mathrm{s}$ drawing speed

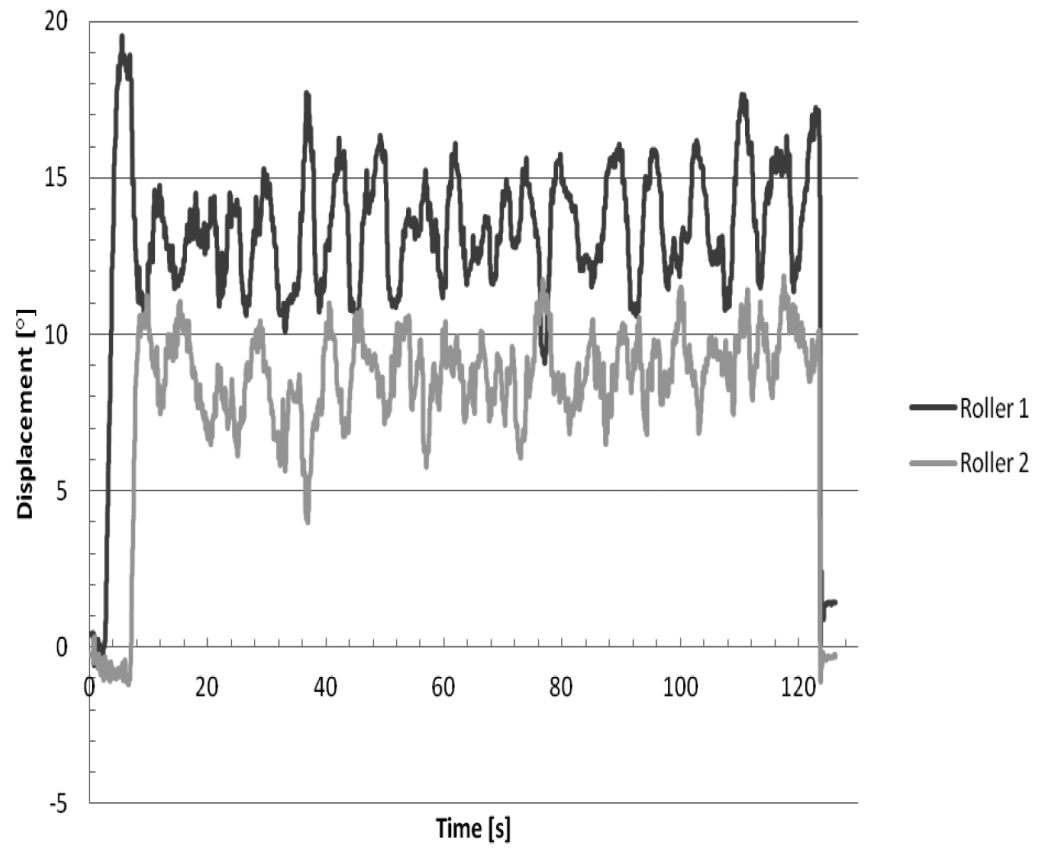

Fig. 9. Rollers displacements measured at $3 \mathrm{~m} / \mathrm{s}$ drawing speed 


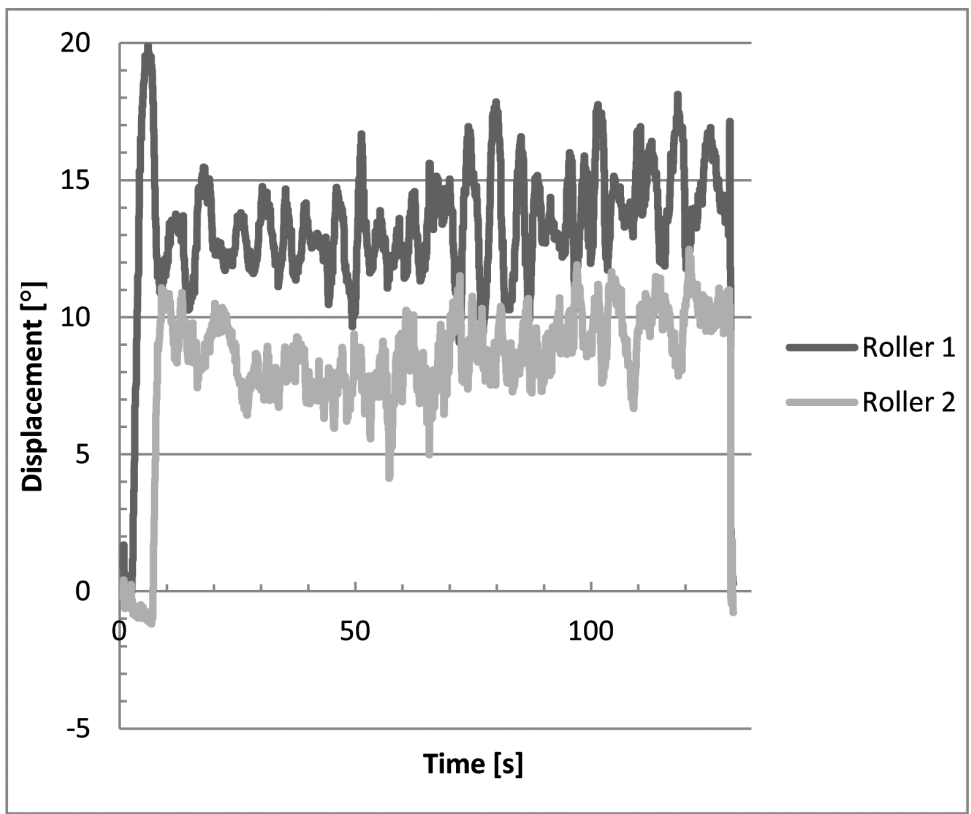

Fig. 10. Rollers displacements measured at $5 \mathrm{~m} / \mathrm{s}$ drawing speed

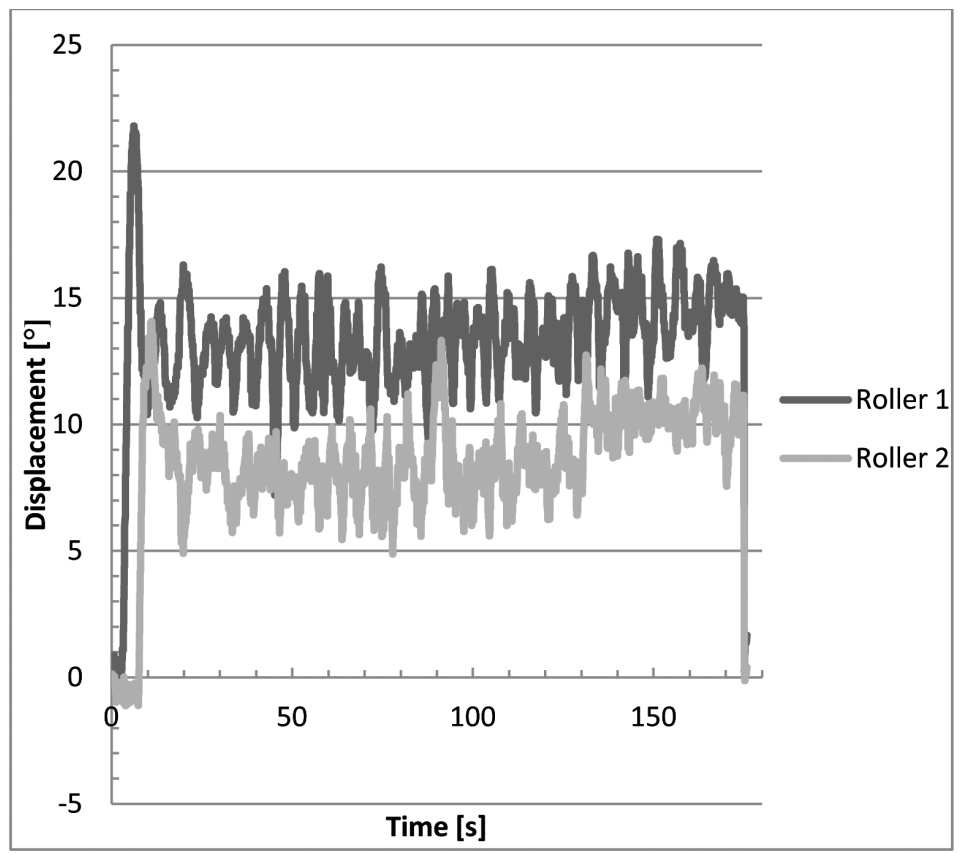

Fig. 11. Rollers displacements measured at $7 \mathrm{~m} / \mathrm{s}$ drawing speed 


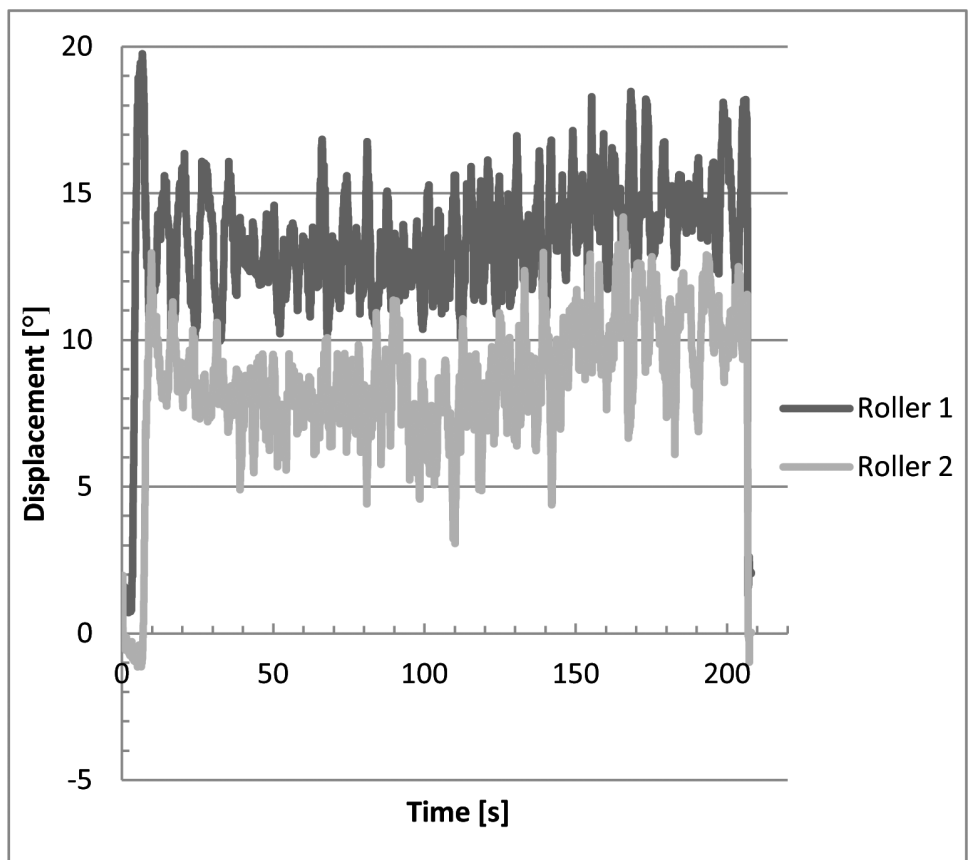

Fig. 12. Rollers displacements measured at $9 \mathrm{~m} / \mathrm{s}$ drawing speed

\section{Conclusions}

Experimental investigations conducted on two stages of a wire drawing machine have been presented in this paper. Based on the experimental results, one analyzed influence of disturbances on two wire drawing stages of the machine during continuous wire drawing through reduction matrices for different drawing speeds, as well as dynamic behavior of the capstans and rollers of the same drawing stages. The analysis performed in this study leads to the following conclusions:

Because of the inhomogeneous deformation in the wire and other stochastic phenomena during the wire drawing process (friction), changes in the wire tensile force occur. These changes directly affect the dynamic behavior of the rollers as well as the mechanical load on the capstans.

Figures 9-12 show the rollers displacement in the function of the drawing speed, which allow us to conclude that they become more unstable as drawing speed increases. The displacements that take place around the set reference values are due to the actions by the controllers that tend to keep these movable mechanical rollers at the given reference positions. The control system must quickly synchronize capstans speeds and thus maintain stable position of the rollers, so wire damage could be avoided. 
By observing the diagrams in Fig. 5 to Fig. 8, one can notice that, with the increase in drawing speed, the pulsating ranges of the capstans speed increase as well, which occurs due to the variability of mechanical load on the capstans, as mentioned above. In the same diagrams, one can also see a constant relationship between the capstans speed of the two drawing stages. This only confirms the fact that a constant reduction ratio is maintained between these stages.

In view of the presented results, the size of the disturbances that occur in this process can be clearly seen. Their analysis may assist tuning control system parameters so the high dynamics of the machine can be improved, leading to increased productivity.

\section{Manuscript received by Editorial Board, June 11, 2014;} final version, February 12, 2015.

\section{REFERENCES}

[1] Rubio E.M., Camacho A.M., Sevilla L., Sebastián M.A.: Calculation of the forward tension in drawing processes. Journal of Materials Processing Technology, 2005, Vol. 162-163, pp. 551-557.

[2] Çetinarslan C.S.: A study on influences of some process parameters on cold drawing of ferrous wire. Indian Journal of engineering \& material sciences, 2012, Vol. 19, pp. 221-228.

[3] Wright R.N.: Wire technology: process engineering and metallurgy, UK, ButterworthHeinemann, Elsevier Inc., 2011.

[4] Lee S.K., Ko D.C., Kim B.M.: Pass schedule of wire drawing process to prevent delamination for high strength steel cord wire. Materials \& Design, 2009, Vol. 30, No. 8, pp. 2919-2927.

[5] Lee S.K., Lee S.B., Kim B.M.: Process design of multi-stage wet wire drawing for improving the drawing speed for $0.72 \mathrm{wt} \% \mathrm{C}$ steel wire. Journal of materials processing technology, 2010, Vol. 210, No. 5, pp. 776-783.

[6] Stevens J.: Variable-speed drives keep machine in sync while drawing fine wire. Chilton's I\&CS, 1995, Vol. 68, No. 7, pp. 31-33.

[7] Antaac: 2007, available at: http://antaac.org.mx.

[8] MacDougall R.L., Camino N.A.: Upgrade dancer arm position control. Wire Journal, 1981, pp. 214-216.

[9] Herzog G.W., Moked M.: Modern multi-block wiredrawing machines. Wire journal international, 1986, Vol. 19, No. 2, pp. 58-62.

[10] Weisheng L., Zhiqin H.: The control system design of the digital fiber drawing machines. Proc. of the 8th World Congress on Intelligent Control and Automation, 2010, pp. 4482-4485.

\section{Pomiary eksperymentalne dynamiki systemu pomiędzy dwoma stopniami ciągarki}

$$
\text { Streszczenie }
$$

Wzrost wydajności ciągarek wielostopniowych można osiągnąć przy wyższych prędkościach jeśli zapobiega się zrywaniu drutu w trakcie procesu ciągnienia. Jedną z niedogodności ciągnienia 
przy dużych szybkościach jest wymaganie, by dynamika systemu zapewniała stabilność i niezawodność działania maszyny. Siły rozciągające w drucie muszą być utrzymane na stałym poziomie przez szybką synchronizację prędkości wszystkich bębnów. Główną rolę w tym procesie pełnią czujniki przemieszczenia, które działają w pętli sprzężenia zwrotnego systemu sterującego dostarczając informacji o stanie drutu. W pracy analizowano oddziaływania między czujnikami i bębnami napędzanymi przez serwomotory i badano doświadczalnie koncepcję zastosowania rolkowego czujnika przemieszczenia w ciągarce wielostopniowej. W tym celu wykonano pomiary na dwu stopniach ciągarki przy różnych prędkościach ciągnienia, a rezultaty zaprezentowano w pracy. Pokazują one, że zmiany prędkości bębnów i przemieszczeń kątowych mechanizmu rolkowego, który utrzymuje drut w napięciu, są bardzo szybkie, co potwierdza dobrą dynamikę sterowania ciągarki. 